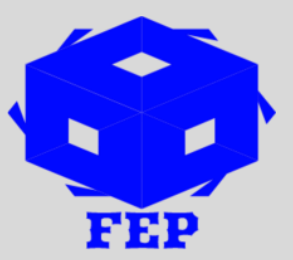

\title{
THE INFLUENCE OF GENERAL INTELLIGENCE AND SOCIAL INTELLIGENCE ABILITY ON STUDENTS ACADEMIC ACHIEVEMENT
}

\author{
Stephen Ndegwa ${ }^{1}$ \\ ${ }^{1}$ Mount Kenya University, Kenya
}

*Corresponding Author: Stephen Ndegwa

Article Received: 23-06-19 Accepted: 25-10-19

Published: 05-11-19

Licensing Details: Author retains the right of this article. The article is distributed under the terms of the

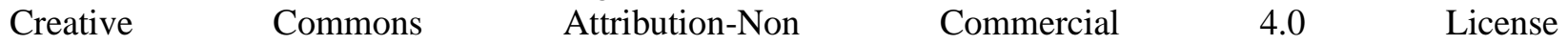
(http://www.creativecommons.org/licences/by-nc/4.0/) which permits non-commercial use, reproduction and distribution of the work without further permission provided the original work is attributed as specified on the Journal open access page.

\section{ABSTRACT}

In this study, the objective was to test the intelligence ability and social intelligence of school students. Standardized questionnaire was used to measure the study variables including social intelligence test, intelligent ability, social intelligence on scholastic achievement for class 10 students in Nairob, Kenya. In this study, data is collected from students on the intelligence ability and social intelligence along with scholastic achievement using the exam score. The findings are that intelligence ability (beta=.786, $\mathrm{P}<.05$ ) and social intelligence (beta=.978, $\mathrm{P}<.05)$ has positive significant effects on student's scholastic achievement. The two factors explain $54.5 \%$ change in the scholastic achievement of students. Our second important finding are that intelligence (beta $=.542, \mathrm{P}<.05$ ) and social intelligence (beta=.657, $\mathrm{P}<.05$ ) has positive and significant influence on students' academic achievement. These factors explain $43.4 \%$ change in the dependent variable. Third main findings are that there is no significant difference between male and female students in terms of mean score of intelligence ability and mean score of social intelligence.

Keywords: Intelligence Ability, social Intelligence, Exam Score, Scholastic Achievement, Students, Kenya.

\section{INTRODUCTION}

The present educational system in many developing countries and even in developed countries poses several challenges to the students. The system is designed in such a manner that it can give 
favor to those who are not intelligent and can put intelligent people in disadvantageous position. In present study, the focus is on understanding the relationship between mindfulness, cognitive therapy and scholastic performance and conduct of marginalized children.

In today's competitive world, success depends on not only intelligence but also requires mutual functioning of intelligence, emotions, and method of coping with day to day demands and stress (Singh \& Koteswari, 2006).

\section{Objectives of the Study}

The objectives of the study are as follows;

-To test the impact of intelligence ability and social intelligence on scholastic achievement of student.

-To test the influence of intelligence and social intelligence on scholastic achievement of their area of interest.

- To study the influence of intelligence ability and social intelligence on the scholastic achievement based on gender

\section{Hypothesis}

Hypotheses of the study are as follows;

-There are significant effects in the mean score of intelligence ability and social intelligence ability on scholastic achievement of students

- There is significant effect in the mean score of intelligence ability and social intelligence on scholastic achievement of male and female students.

Based on above hypotheses and objectives of the study, our independent variables include intelligence ability, social intelligence, and gender; while, our dependent variable is scholastic achievement

\section{Limitation of the Study}

The limitations of the study include small sample size drawn from single school and single city. The limitation is also that we only focused on students of class 10 and did not include other class or level students.

\section{Sample}

\section{RESEARCH METHODOLOGY}

We used simple random sampling and stratified random sampling for selecting particular sample. Our sample consisted of 296 students from different branches of same school in a single city. In our sample, there were 136 male students and 160 female students.

\section{Data Collection Method}

We used cross-sectional survey for data collection. A survey was designed based on previously developed measure which was distributed and get filled from the students. In our survey, we measured intelligence ability by measure developed by Desai which measure verbal and nonverbal group intelligence test. Social intelligence is measured by measure developed by Chadda and Gianeshan (2004). Scholastic achievement is measured by exam results of class 10. 


\section{Data Analysis and Interpretation:}

Data analysis is done using the SPSS version 20 and main analysis techniques include frequency analysis and t-statistics.

Results are as follows.

\section{RESULTS}

Table 1

Impact in the mean score of Intelligence ability and social Intelligence on scholastic achievement

\begin{tabular}{lccc}
\hline & Beta value & t-stat & P-Value \\
\hline Constant & .334 & .878 & .984 \\
Intelligence Ability & .886 & 2.878 & .004 \\
Social Intelligence & .988 & 3.454 & .000 \\
\hline Rsquare & .545 & & \\
Fstat & $78.44(.000)$ & & \\
\hline
\end{tabular}

We tested the influence of intelligence ability and social intelligence ability on scholastic achievement of students using the analysis provided above. Results shows that intelligence ability has positive and significant effects on scholastic achievement with beta value of .886 and $\mathrm{p}$ value of .004. Similarly, social intelligence has positive and significant effects on scholastic achievement with beta value of .988 and $\mathrm{p}$ value of .000 . Both factors explain $54.5 \%$ change in the dependent variable of scholastic achievement. The overall model is fit and significant as clear from its $F$ value of 78.44 .

Table 2

Impact of Intelligence and social Intelligence on scholastic achievement

\begin{tabular}{llll}
\hline & Beta value & t-stat & P-Value \\
\hline Constant & .119 & .987 & .834 \\
Intelligence & .542 & 2.032 & .001 \\
Social Intelligence & .657 & 2.756 & .000 \\
\hline Rsquare & .434 & & \\
Fstat & $22.564(.000)$ & &
\end{tabular}

The results show that intelligence has positive and significant effects on scholastic achievement with beta value of .542 and $\mathrm{p}$ value of .001. Similarly, social intelligence has positive and significant effects on scholastic achievement with beta value of .657 and p value of .000 . The two factors explain $43.4 \%$ variation in student's scholastic achievement. The overall model is fit and significant as clear from its $\mathrm{F}$ value of 22.564 .

Table 3

\begin{tabular}{llll}
\multicolumn{4}{c}{ Mean Score Comparison between Gender } \\
\hline & Male & Female & t-stat (p value) \\
\hline Mean Score- Intelligence Ability & 433.8 & 439.9 & $1.132(0.097)$ \\
Mean Score- Social Intelligence & 185.32 & 194.32 & $1.657(0.086)$
\end{tabular}

Based on our results, we found that means core for male student was 433.8 and female student was 439.9 but the statistical difference was insignificant as t value was less than 1.96. Similarly, 
the mean score for social intelligence for male students was 185.32 and female students was 194.32 and this difference was also statistically insignificant. Overall, our results show that there is no statistically difference between male and female students intelligence ability and social intelligence score.

Based on our results, our key findings are that student's intelligence ability is positively correlating with scholastic achievement. Second main finding is that social intelligence of students is positively correlating with scholastic achievement of students. Third main finding is that intelligence ability and social intelligence has positively significant effects on student's scholastic achievement. Fourth main findings are that there is no significant difference of students score on intelligence ability and social intelligence based on gender.

\section{CONCLUSION}

Based on the findings of the study, it can be concluded that intelligence ability and social intelligence are important for student's academic success. In other words, if a student lacks intelligence ability or social intelligence, so his/her chances of becoming successful in academic life will be very low. This means that if student lack intelligence ability or social intelligence, then right therapy and counselling is required in order to enhance their intelligence ability and social intelligence.

\section{Recommendations}

- Our recommendation is that parents should focus on testing and improving the intelligence ability and social intelligence of their children.

- Teachers should focus on improving the social intelligence and general intelligence ability of students.

-Efforts should be made to improve student's intelligence ability and social intelligence.

\section{References}

Barton, K., Dielman, T. E., \& Cattle R. B. (1972). Personality and IQ measures as predictors of school achievement. Journal of educational psychology, 64(4), 398-400.

Chadda, N. K., \& Ganeshan, G. (2004). Manual for social Intelligence scale. National psychological corporation, Agra

Desai, K. G. (1992). Institute of psychology and Edu. Research and Guidance, Ahmadabad

Kuppuswamy, B. (1995). Elements of social psychology. Konark publishers Pvt. Ltd. 